\title{
The Analysis of Influencing Factors of Performance of Community Time Bank Mutual Assistance Services Based on SEM Model Empirical Data from Nansha District, Guangzhou, China

\author{
Daoqin Pan \\ Guangdong University of Foreign Studies, China \\ Phone: +8618664527796
} \\ E-mail:857362351@qq.com
}

China

Yijing Wu

Hong Kong Baptist University, China

Phone: +00852 68557457

E-mail:19414099@life.hkbu.edu.hk

China

\section{ABSTRACT}

Based on the 3E Methodology, in this study, the performance of community time bank mutual assistance services are empirically evaluated from three aspects of economy, effectiveness, and efficiency. We investigate and then hypothesize four impacts that affect the performance of community time bank mutual assistance services, including external supervision, organizational credibility, organizational management, and public welfare atmosphere. Therefore, the empirical data from Nansha District, Guangzhou, China, and the Structural Equation Model are used to empirically test the above hypotheses. The results show that: first, the performance of community time bank mutual assistance services is at a medium level; second, external supervision has a positive effect on the efficiency and effectiveness of time bank mutual assistance services, but no significant relationship with economy; third, organizational credibility has a positive effect on the efficiency and effectiveness, but no significant relationship with economy; forth, organizational management has a positive effect on the economy, efficiency and effectiveness; fifth, public welfare atmosphere has a positive effect on the efficiency, but no significant relationship with economy and effectiveness. Based on the above results, four policy recommendations to promote the sustainable development of community time bank mutual assistance services are also provided.

\section{KEYWORDS: Time banks; Mutual assistance services; Performance influencing factors; 3E Methodology; Structural Equation Method}

\section{Introduction}

The concept of time bank was proposed by Professor Edgar S. Cahn in the 1980s. It was designed to solve the social problems caused by the high unemployment rate and economic recession at the time. In time banks, the idle human resources in the society were reasonably integrated and fully used. Its basic idea is the direct exchange of time-one hour of service to others in exchange for one hour to be served by others-and the core idea is to help each other.

To solve the social problems caused by the aging population, time banking was introduced to China in the 1990s, and mainly used in the field of old-age care at home. So far, although time banking has been practiced in China for more than 20 years, and the foreign practice has proven its positive effect on society, it has not yet been widespread in China. Many time banks even went out of business only a few months after its establishment.

To help time banks develop and realize their functions better, many studies have been carried out from the perspectives of time banking's concept, function, problems and further development. Regarding the research on the concept of time banking, Reference [2] shows that the development of time bank is helpful to the construction of the Core Economy which is an economic system that helps communities, families, friends and relatives to help each other. It cannot be measured by money, but supports the normal operation of the monetary economy, and therefore deserves more attention. Reference [6] then 


\author{
E-ISSN: 2469-6501 \\ VOL: 6, ISSUE: 2 \\ February/2020 \\ DOI:10.33642/fjbass.v6n2p1 \\ https://ijbassnet.com/
}

proposes that as an innovation of the Social Economy including the voluntary and community organizations as well as community enterprises, time banking promotes its development and realizes its functions. Based on the Chinese practice of time banking, its substance is also studied, including the intergenerational exchange of labor services [9], a deferred payment of labor results [5] and a credit product [23]. Reference [25] defines time banking in both broad and narrow sense, and considers its essence as volunteering and meanwhile enjoying other's volunteering.

Concerning the studies on the functions of time banking, Reference [14] and [24] believe that time banking is an important supplementary form of pension practice in China. It provides a platform for the elderly to continue realizing their value, meet the spiritual needs of the elderly, help them get equal respect and sense of achievement [22], and achieve active ageing by regaining the social capital that is comprehended as social networks and related reciprocity systems [12]. Reference [3] analyzes of 87 months of transaction data from time banks and 950 members of them, and finds that the participation of the elderly is as active as others, making important contributions to the community, and the elderly themselves also benefit from time banks, which is a manifestation of active aging. As a form of paid help, time banking is conducive to the cultivation of a social public welfare atmosphere, arouses people's enthusiasm for volunteering [16], fosters a social atmosphere that people are more helpful [25], and carries forward the tradition of mutual help among neighbors [11]. Also, time banking is acknowledged to be an approach to reuse the idle resources in the society and broaden the source of elderly care services, such as reusing the resources of the younger part of elderly people whom have been paid little attention to previously [11]. The incentive concept of Token Economies is practiced by time banks in the social work of idle teenagers by encouraging them to complete public welfare activities [18]. Reference [1] shows that in time banks, community residents are regarded as the center of public affairs and are encouraged to participate. This innovative mutual assistance mode allows the public service and welfare system to continue operating effectively. Reference [7] finds that many members of time banks come from marginal social groups that are difficult to reach in normal times. Contributing to solve the problem of social exclusion, time banks promotes mutual help inside and outside social marginal groups, which promotes the mutual understanding and helps social marginal groups gain recognition and integrate into the society. Reference [13] also finds that time banks allow residents to participate in mutual assistance services to improve health level, and help local health centers to treat community health issues from a broader perspective, which is also beneficial to the community residents' health.

Regarding the problems and further development of time banks, studies show that major problems include the lack of government and policy support [6], [21], service risk [5], weak credibility [10], problems of deposit and withdrawal [14] and low degree of popularity [4], [20]. To solve these problems, actions need to be taken. First government and policy support should be strengthened and various rules of time banks ought to be clarified and standardized to regulate its operation [8]. Second, the organization of time banks should be coordinated to ensure consistency between front-line employees and their leaders, which contributes to the common understanding of different targets of the time bank and the supply and demand of mutual assistance services [17]. Third, to expand the social influence and radiation effect of time banks as well as attract more residents, time banks should rely on the good reputation of its founders and increase publicity by actively cooperating with the modern media [22]. Forth, a standard information system should be established and play the function of exchanging and circulating resources to permanently store relevant information and data, and facilitate interbank deposit and withdrawal [4].

In conclusion, existing studies have explored time banking from different perspectives such as the origin, concept, function, problems and further development. However, most of the existing studies use qualitative analysis, and the quantitative analysis is relatively lacking. Moreover, as China's ageing problem is more and more serious, time banking is first practiced in the elderly care field in China to cope with the ageing problem. Studies from China also focus on the same field, but few studies focus on the use of time banks in other fields. Finally, there is still a lack of research on the performance of time banks at present.

Therefore, the empirical data from Nansha District, Guangzhou, China is used as a sample to construct a Structural Equation Model of community time bank mutual assistance service performance and its influencing factors. Combined with the analysis of the interview result, relevant policy suggestions for the development of time banks are also provided in this paper. Our study has a certain degree of innovation and theoretical as well as practical significance. Theoretically, the theoretical research in the field of time banking is further enriched, and the theoretical support for other researches on time 
banking in the future is provided. Practically, the results of this paper are helpful for time banks to identify relevant influencing factors and thus improve its performance, which will benefit its sustainable development and hence solve the social problems and implement the community functions in the context of social transformation.

The rest of this paper is organized as follows: in the second part relevant theories are analyzed and research hypotheses are proposed; in the third part the empirical design is introduced; in the fourth part the empirical results are shown; and finally the main conclusions and policy recommendations are discussed.

\section{Methodology and Hypothesis}

\section{A. 3E Methodology}

In the early 1980s, 3E methodology, including Economy, Efficiency and Effectiveness, was proposed by the British Efficiency Group. Most scholars use the methodology of $3 \mathrm{E}$ as a general principle of government performance evaluation. Economy requires that public goods or services of a given quantity and quality should be provided at the lowest possible cost. Efficiency is the proportional relationship between input and output. Effectiveness is usually measured by the relationship between the output and outcome.

\section{B. Variables of Community Time Bank Mutual Assistance Service Performance}

3E Methodology was applied in studying the performance of municipal environmental public expenditure. The economy of fiscal expenditures refers to achieving the set goals and tasks with the least expenditure of resources while ensuring the quality; efficiency means that compared with the amount of resources spent to achieve the goals, the greatest possible contribution to the given objectives; effectiveness refers to the effect of public expenditure that led by the largest possible output [15]. In the study of time banking performance, economy means that the investment of time banks should meet the need of its operation, and the demands of its members with limited resources. Also, during its operation, the waste of manpower, material and funds should be avoided. Efficiency refers to the relationship between the input and output of time banks, and is used to evaluate the quantity and quality of time banks in a set input. Effectiveness refers to the impact that time banks have on the members, community, and society.

1) Variables of Economy: The capital investment on time banks mainly includes both material and human resources. The investment of facilities greatly affects the coverage of services provided by time banks. The quality of infrastructure and specialized equipment also directly affects the service experience. Secondly, the competency of time banks' staff has a directly impact on the efficiency of resource utilization. The number of staff should also match the size of time bank to maintain its normal operation. Therefore, the observed variables used to measure econo my are: Material Resource Input, Human Resource Input 1 and Human Resource Input 2. The Questionnaire items are set as A1, A2 and A3.

2) Variables of Efficiency: Firstly, in a certain period, the number of services that the time bank platform has successfully matched not only reflects the timeliness of the information processing, but it also shows that the platform can quickly and accurately filter out valid information for matching. Secondly, the time bank is a platform for matching and providing services to the public. The members' evaluation of the services is the most intuitive reflection of the quality. Therefore, the observed variables used to measure efficiency are: Service Amount and Service Quality. The Questionnaire items are set as A4 and A5.

3) Variables of Effectiveness: For the community residents, time banks help the residents get to know each other better and promote the cohesion of the community. From the perspective of the whole society, time banks enable young and capable residents to provide services for the elderly, and play a role in alleviating the pressure of social endowment. At the same time, time banks also provide opportunities for social marginal groups to reintegrate, which is conducive to the construction of a harmonious society. Therefore, the observed variables used to measure effectiveness are: Personal Effect, Community Effect 1 , Community Effect 2 and Social Effect. Questionnaire items are set as A6, A7, A8 and A9. 


\section{International Journal of Business and Applied Social Science}

\section{TABLE I}

wwW.cpernet.org

\begin{tabular}{c|c|c|l}
\multicolumn{4}{c}{ VARIABLES OF COMMUNITY TIME BANK MUTUAL ASSISTANCE SERVICE PERFORMANCE } \\
\hline $\begin{array}{c}\text { latent Dependent } \\
\text { Variable }\end{array}$ & Item & Observed Variable & \\
\hline \multirow{3}{*}{ Economy } & A1 & Material Resource Input & Whether the facilities invested on the time bank meet its demand \\
\cline { 2 - 4 } & A2 & Human Resource Input 1 & Measuring labor input by the number of employees \\
\cline { 2 - 4 } & A3 & Human Resource Input 2 & Satisfaction with the quality of services provided by the staff. \\
\hline \multirow{2}{*}{ Efficiency } & A4 & Service Amount & The number of requests successfully accepted per unit time \\
\cline { 2 - 4 } & A5 & Service Quality & The frequency that the service is well received \\
\hline \multirow{3}{*}{ Effectiveness } & A6 & Personal Effect & Individual attention to mutual help in the neighborhood \\
\cline { 2 - 4 } & A7 & Community Effect 1 & The number of new friends made after participation \\
\cline { 2 - 4 } & A8 & Community Effect 2 & Community harmony \\
\cline { 2 - 3 } & A9 & Social Effect & Elderly participation \\
\hline
\end{tabular}

\section{Hypothesis}

1) External Supervision and Community Time Bank Mutual Assistance Service Performance: The external supervision refers to the Supervision by individuals or units that are independent of time banks, including members, third-party institutions, and the government.

Members benefit directly from community time bank mutual assistance services. To better protect their interests, members will supervise the use of resources of the time bank platform, which helps find their problems and thus improve their economy. At the same time, members will evaluate the service effect based on their most intuitive feelings about the quantity and quality of services. Then they will provide feedback to time banks to urge them to adjust the rules of the platform, which will help enhance the efficiency and effectiveness of community time bank mutual assistance services.

Third-party assessment agencies are mostly appointed by the clients of time banks, and are composed of experienced persons in related majors such as the college professors. Although the third-party assessment agency is not a direct participant in the community time bank mutual assistance services, it conducts professional research and scientific qualitative and quantitative analysis. It can more professionally and accurately assess whether the time bank's resources are fully utilized and its operation is efficient and effective, and hence promotes the economy, efficiency and effectiveness of community time bank mutual assistance services.

As the stakeholder of time banks, the government invests funds and provides various support. Therefore, the government will pay close attention to the use of resources, such as manpower and material resources, and its output, which plays a role of supervision towards time banks. At the same time, the government's evaluation of its operating process will also affect the efficiency of community time bank mutual assistant services. People's livelihood is the focus of the government. Through the supervision of time banks, the government will provide relevant opinions on how time banks further improve people's livelihood, which will enhance the effectiveness.

Thus, the hypotheses about the impact of external supervision on community time bank mutual assistance services are proposed below:

Hypothesis 1: Community time bank mutual assistance service performance will be positively affected by external supervision.

Hypothesis 1-1: External supervision will positively affect the economy of community time bank mutual assistance service performance.

Hypothesis 1-2: External supervision will positively affect the efficiency of community time bank mutual assistance service performance.

Hypothesis 1-3: External supervision will positively affect the effectiveness of community time bank mutual assistance service performance.

2) Organizational Credibility and Community Time Bank Mutual Assistance Service Performance: Organizational credibility is the ability and degree of social organizations to win the trust and support of the government and society [19]. The 
credibility of time banks is derived from residents' awareness, praise and trust of community time bank mutual assistance services.

If the popularity of the community time bank mutual assistance services is high, the cost on publicity will be reduced, exerting a positive effect on its economy. With the increase of popularity, there will be more participants and to ensure the normal operation of the platform, time banks will strive to improve its efficiency. The increase in the number of participants also demands a larger scale of time banks, which will benefit more residents and even the whole society. Thus, its effectiveness is improved.

The praise from participants enables them to actively recommend this new type of mutual assistance services to their relatives and friends, which also saves extra publicity expenses. Moreover, the residents' trust on time banks gets themselves involved in the services at ease. Therefore, more praise and trust on time banks will improve its economy, efficiency and effectiveness.

Thus, the hypotheses about the impact of organizational credibility on community time bank mutual assistance services are proposed below:

Hypothesis 2: Community time bank mutual assistance service performance will be positively affected by organizational credibility.

Hypothesis 2-1: Organizational credibility will positively affect the economy of community time bank mutual assistance service performance.

Hypothesis 2-2: Organizational credibility will positively affect the efficiency of community time bank mutual assistance service performance.

Hypothesis 2-3: Organizational credibility will positively affect the effectiveness of community time bank mutual assistance service performance.

3) Organizational Management and Community Time Bank Mutual Assistance Service Performance: Organizational management refers to the establishment of an appropriate organizational structure, rules, regulations and the rational use of resources. Organizational management aims to effectively allocate limited resources to better achieve organizational goals.

The organization structure of time banks reflects the division of labor and cooperation inside time banks. If there are too many departments and managers in time banks, the investment will not be fully utilized, whereas if they are not enough, each staff member will need to bear an excessive workload, which will cause the problem of low quality. If the time bank's organizational structure is set up reasonably and scientifically, the staff will perform their duties well, and the work content will not be duplicated. In this case, the departments are interconnected, and the work transfer is orderly, thereby greatly improving the efficiency of time bank operations. At the same time, a reasonable division of labor and cooperation not only promotes the steady development of Time Bank towards its set goals, but also helps to win public response and participation. The high-quality mutual assistance experience will have a positive impact on residents' personal development, community harmony and social progress, thereby promoting the effectiveness of Time Banking.

The higher the Time Bank's standardization, the more internal staff must follow the rules, which can make the greatest use of the input. At the same time, in terms of purchasing equipment required for Time Banking operations, the staff will purchase on demand under rules and regulations, without using waste, so that material input can be guaranteed and fully utilized. And the staff of Time Banking earnestly abides by the laws and regulations and the rules and regulations of the organization, without speculation or laziness. Therefore, the smooth operation of Time Banking can be more guaranteed, and the efficiency will be improved accordingly.

The scientific and reasonable rule setting is conducive to ensuring the smooth conduct of Time Banking activities every time, and also to protect the rights and interests of members. When members get their due rights, they will trust the time bank more. Such a conscience cycle will promote the improvement of the Time Bank's economy, efficiency and effectiveness.

In summary, this article puts forward the following assumptions about the impact of organizational management on Time Banking performance below. 
Hypothesis 3: Community time bank mutual assistance service performance will be positively affected by organizational management.

Hypothesis 3-1: Organizational management will positively affect the economy of community time bank mutual assistance service performance.

Hypothesis 3-2: Organizational management will positively affect the efficiency of community time bank mutual assistance service performance.

Hypothesis 3-3: Organizational management will positively affect the effectiveness of community time bank mutual assistance service performance.

4) Public Welfare Atmosphere and Community Time Bank Mutual Assistance Service Performance: The public welfare atmosphere refers to the atmosphere of participating in public welfare activities. Both the frequency of participation and the amount of participation channels reflect the regional public welfare atmosphere.

The increasing frequency of participating in public welfare activities and the variety of channels make people more willing to help others. Because time banking focuses on mutual assistance, warmhearted people are more likely to join in it. Therefore, time banks can have sustainable development, and investment can also be utilized.

To have a better experience, members of time banks would like to strengthen the supervision of time banks and make suggestions. When time banks adopt members' suggestions and make improvements, its efficiency will be enhanced. On the other hand, people who often take part in other public welfare activities will be like to advise time banks for reference. The reference from other welfare activities also helps time banks enhance their efficiency.

A good public welfare atmosphere helps people improve their willingness of participating in time banks. However, the interaction between participants and time banks is mutual. On the one hand, residents help Time Banking improve its efficiency by supervision and reference. On the other hand, time banks also have positive effects on the personal development of individuals, communities and the whole society.

Thus, the hypotheses about the impact of the public welfare atmosphere on community time bank mutual assistance services are proposed below:

Hypothesis 4: Community time bank mutual assistance service performance will be positively affected by public welfare atmosphere.

Hypothesis 4-1: Public welfare atmosphere will positively affect the economy of community time bank mutual assistance service performance.

Hypothesis 4-2: Public welfare atmosphere will positively affect the efficiency of community time bank mutual assistance service performance.

Hypothesis 4-3: Public welfare atmosphere will positively affect the effectiveness of community time bank mutual assistance service performance.

Based on the assumptions above, this article proposes the following logical framework (Fig. 1).

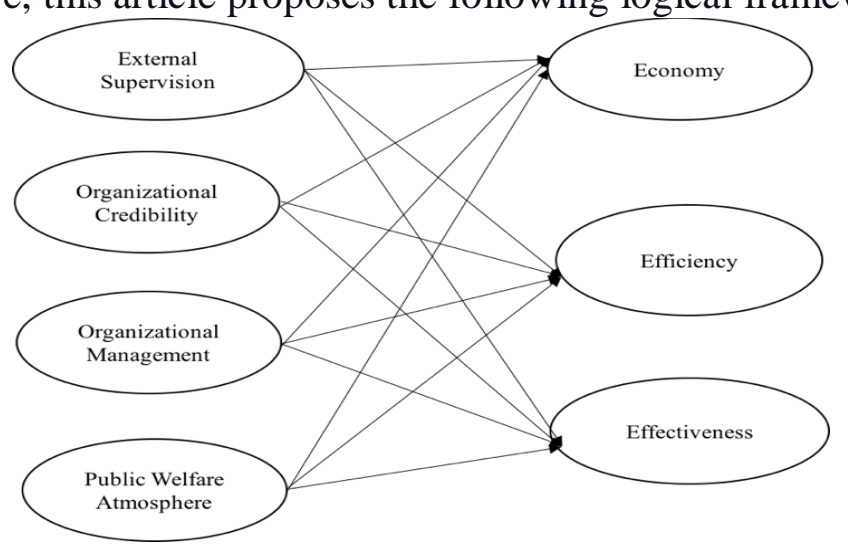

Fig. 1 Logical framework of the relationship between community time bank mutual assistance service performance and its influencing factors 


\section{Empirical Design}

\section{A. Research Method}

Structural Equation Model was used for this empirical research. Structural Equation Model (SEM) is a research method based on statistical analysis that uses a linear equation system to represent the relationship between observed variables and latent variables, as well as the relationship between latent variables. It is a generalized general linear model. The purpose of it is to explore the linear relationship among variables. By creating a Structural Equation Model of the performance and influence factors of the time bank community mutual assistance services, this paper explores the influencing factors and their mechanism of the time bank community mutual assistance service performance.

\section{B. Variable Selection}

1) Variables of External Supervision: Firstly, members' supervision is a major element of external supervision of time banks. The unobstructed supervision channels for members will make the supervision more effective. Secondly, Third-party supervision, which is independent of members and time banks, has a high degree of independence. Its participation is an effective supplement to the external supervision system of time banks. Thirdly, as the government is the main investor of time banks, its supervision is the most effective. Therefore, the observed variables used to measure external supervision are Member Supervision Channel, Third-party Supervision and Government Supervision. The questionnaire items of these variables are B1, B2, and B3.

2) Variables of Organizational Credibility: From the perspective of hierarchy, organizational credibility can be composed of awareness, reputation, and trust. Awareness is the basic and necessary condition for public recognition of time banks. If the public does not know or understand time banking, then there is no way to talk about the recognition of time banking. When people know and understand time banking, they will have a satisfactory or unsatisfactory attitude towards it, that is, reputation degree. When people's satisfaction with time banking is high, it is possible to turn goodwill into action. Therefore, people will trust and participate in time banks. As a result, the credibility of time banks will be improved. In this way, the observed variables used to measure organizational credibility are: Awareness, Reputation, and Trust. The questionnaire items of these variables are B4, B5, and B6.

3) Variables of Organizational Management: An appropriate structure, scale, and rules set will help time banks more independent as a third-party platform. Therefore, time banks can balance demands and the supplies of services effectively, and then improve performance. As a platform for mutual assistance services, in order to ensure the completion of each service, it is necessary to set rules scientifically to protect the rights and interests of members. In this way, the observed variables used to measure organizational management are Organizational Structure, Organizational Standardization and Activity Rules Settings. The questionnaire items of these variables are B7, B8, and B9.

4) Variables of Public Welfare Atmosphere: The frequency of public welfare participation is a direct reflection of the public welfare atmosphere. Participation channels are guarantees for participation in public welfare. Unobstructed channels for public welfare participation set up by governments are good for residents to learn about information and participate in. Then, a strong public welfare atmosphere will be formed and providing an atmosphere foundation for the development of time banks. Therefore, the observed variables used to measure the public welfare atmosphere are Participation Frequency and Public Welfare Participation Channel. The questionnaire items of these variables are B10 and B11.

In summary, the definitions of the influence variables are shown in Table II. The relationship between the variables is shown in the SEM diagram (see Fig. 2). 


\section{TABLE II}

\section{DEFINITIONS OF THE INFLUENCE VARIABLES}

\begin{tabular}{c|c|c|l}
\hline Latent Variable & Item & Observed Variable & \multicolumn{1}{c}{ Meaning } \\
\cline { 2 - 4 } External Supervision & B1 & Member Supervision Channel & The amount of channels for members to supervise time banks. \\
\cline { 2 - 4 } & B2 & Third-party Supervision & Members' satisfaction with the frequency of third-party supervision of time banks. \\
\cline { 2 - 4 } $\begin{array}{c}\text { Organizational } \\
\text { Credibility }\end{array}$ & B3 & Government Supervision & Member satisfaction with government oversight. \\
\cline { 2 - 4 } & B5 & Awareness & Residents' understandings of time banking. \\
\cline { 2 - 4 } $\begin{array}{c}\text { Organization } \\
\text { Management }\end{array}$ & B6 & Reputation & Members' satisfaction with time banks. \\
\cline { 2 - 4 } & B7 & Trust & Members' trust in time banks. \\
\cline { 2 - 4 } $\begin{array}{c}\text { Public Welfare } \\
\text { Atmosphere }\end{array}$ & B9 & Organizational Standardization & Members' satisfaction with time bank standardization. \\
\cline { 2 - 4 } & B11 & Partivity Rules Setting & Members' satisfaction with time banks' rules settings. \\
\hline
\end{tabular}

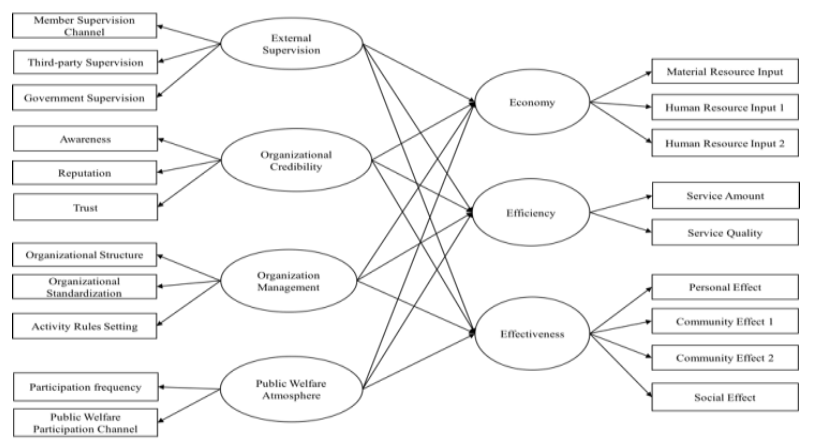

Fig. 2 SEM diagram

\section{Sample and Data Collection Procedure}

At present, the overall development of time banks in China is relatively slow. Compared with other domestic time banks. Nansha Time Bank has a more advanced and innovative operating model. It has been developing steadily since its establishment in 2013. Also, it has achieved relatively good results. In this work, a total of 305 questionnaires were collected from Nansha Time Bank. And there are 303 valid questionnaires. The demographic characteristics are shown in the following table.

TABLE III

\section{DEMOgRAPHIC CHARACTERISTICS}

\begin{tabular}{|c|c|c|c|}
\hline & Category & Frequency & Percentage $(\%)$ \\
\hline \multirow{2}{*}{ Gender } & Male & 68 & 22.4 \\
\hline & Female & 235 & 77.6 \\
\hline \multirow{4}{*}{ Age } & Under 30 & 40 & 13.2 \\
\hline & $30-45$ years old & 120 & 39.6 \\
\hline & $46-60$ years old & 121 & 39.9 \\
\hline & Over 60 years old & 22 & 7.3 \\
\hline \multirow{3}{*}{ Education } & Primary school & 29 & 9.6 \\
\hline & Junior school & 16 & 5.3 \\
\hline & High school & 83 & 27.4 \\
\hline
\end{tabular}




\begin{tabular}{|c|c|c|c|}
\hline & Category & Frequency & Percentage (\%) \\
\hline & Junior college & 93 & 30.7 \\
\hline & Undergraduate & 74 & 24.4 \\
\hline & Postgraduate & 6 & 2.0 \\
\hline & $\mathrm{PhD}$ and above & 2 & 0.7 \\
\hline \multirow{9}{*}{ Occupation } & Retired & 33 & 10.9 \\
\hline & Civil servant & 37 & 12.2 \\
\hline & Senior executives & 47 & 15.5 \\
\hline & Social worker & 35 & 11.6 \\
\hline & Doctor/teacher/lawyer & 3 & 1.0 \\
\hline & Freelancers & 20 & 6.6 \\
\hline & $\begin{array}{l}\text { Scientific research/engineering/ } \\
\text { technical personnel }\end{array}$ & 4 & 1.3 \\
\hline & Corporate general staff & 114 & 37.6 \\
\hline & Others & 10 & 3.3 \\
\hline
\end{tabular}

The survey has 20 questions in 7 dimensions, including Economy, Efficiency, Effectiveness, External Supervision, Organizational Credibility, Organizational Management, and Public Welfare Atmosphere. As shown in Table IV, the minimum value of each variable is 1 , and the maximum value is 7 . The standard deviation of each variable exceeds 1 , except for Material Resource Input, Trust, Organizational Structure, Organizational Standardization, and Activity Rules settings.

\section{TABLE IV}

\section{DESCRIPTIVE STATISTICS}

\begin{tabular}{|c|c|c|c|c|c|}
\hline & $\mathbf{N}$ & Min & Max & $\mathbf{M}$ & S.D. \\
\hline Material Resource Input & 303 & 1 & 7 & 5.04 & .9602 \\
\hline Human Resource Input 1 & 303 & 1 & 7 & 5.03 & 1.0111 \\
\hline Human Resource Input 2 & 303 & 1 & 7 & 5.28 & 1.0111 \\
\hline Service Amount & 303 & 1 & 7 & 3.72 & 1.1461 \\
\hline Service Quality & 303 & 1 & 7 & 4.06 & 1.2787 \\
\hline Personal Effect & 303 & 1 & 7 & 5.15 & 1.1192 \\
\hline Community Effect 1 & 303 & 1 & 7 & 5.10 & 1.1541 \\
\hline Community Effect 2 & 303 & 1 & 7 & 5.16 & 1.1204 \\
\hline Social Effect & 303 & 1 & 7 & 5.10 & 1.2557 \\
\hline Member Supervision Channel & 303 & 1 & 7 & 4.91 & 1.3899 \\
\hline Third-party Supervision & 303 & 1 & 7 & 4.66 & 1.1330 \\
\hline Government Supervision & 303 & 1 & 7 & 4.66 & 1.1310 \\
\hline Awareness & 303 & 1 & 7 & 4.96 & 1.1546 \\
\hline Reputation & 303 & 1 & 7 & 5.80 & .9562 \\
\hline Trust & 303 & 1 & 7 & 6.04 & 1.0494 \\
\hline Organizational Structure & 303 & 1 & 7 & 4.91 & .8910 \\
\hline Organizational standardization & 303 & 1 & 7 & 5.09 & .9431 \\
\hline Activity Rules setting & 303 & 1 & 7 & 5.14 & .9575 \\
\hline Participation Frequency & 303 & 1 & 7 & 5.56 & 1.2587 \\
\hline Public Welfare Participation Channel & 303 & 1 & 7 & 5.56 & 1.2377 \\
\hline Valid N (listwise) & 303 & & & & \\
\hline
\end{tabular}

\section{Variables Measurement}

1) Reliability Testing: The reliability test shows that, except for External Supervision, the Cronbach's $\alpha$ coefficients of other latent variables are between 0.763 and 0.907 , indicating that the questionnaire has a high inherent consistency. 
2) Validity Testing: Through the validity test, the results of $\mathrm{KMO}$ are 0.883 , and Bartlett's spherical test results are significant, indicating that the sample data is suitable for factor analysis.

3) Principal Component Analysis: After the principal component analysis of 9 community time bank mutual assistance service Performance variables and 11 influencing factor variables, the rotated component matrix is obtained (see Table V). And 7 dimensions are summarized, which are consistent with the assumptions and variable selections described above.

TABLE V

ROTATED COMPONENT MATRIX ${ }^{\mathrm{a}}$

\begin{tabular}{|c|c|c|c|c|c|c|c|}
\hline & \multicolumn{7}{|c|}{ Component } \\
\hline & 1 & 2 & 3 & 4 & 5 & 6 & 7 \\
\hline Material Resource Input & .270 & .840 & .017 & .010 & .038 & .162 & .231 \\
\hline Human Resource Input 1 & .159 & .771 & .154 & .092 & .121 & .156 & .405 \\
\hline Human Resource Input 2 & .398 & .780 & .137 & .156 & .066 & .162 & .097 \\
\hline Service Amount & .264 & .234 & .290 & .207 & -.057 & .732 & .051 \\
\hline Service Quality & .344 & .252 & .020 & .134 & -.051 & .810 & .123 \\
\hline Personal Effect & .788 & .353 & .016 & .213 & -.102 & .124 & .165 \\
\hline Community Effect 1 & .751 & .169 & .097 & .167 & .091 & .292 & .118 \\
\hline Community Effect 2 & .859 & .206 & .030 & .210 & -.046 & .090 & .218 \\
\hline Social Effect & .702 & .206 & .135 & .152 & .118 & .430 & .146 \\
\hline Member Supervision Channel & -.178 & -.075 & .612 & .046 & .501 & .167 & .217 \\
\hline Third-party Supervision & .032 & .120 & .109 & .028 & .887 & -.007 & .015 \\
\hline Government Supervision & .033 & .039 & .174 & .080 & .881 & -.042 & .067 \\
\hline Awareness & .124 & -.080 & .249 & .593 & .158 & .516 & .121 \\
\hline Reputation & .158 & .144 & .064 & .888 & .031 & .112 & .099 \\
\hline Trust & .276 & .073 & .122 & .842 & .048 & .114 & .141 \\
\hline Organizational Structure & .268 & .336 & .121 & .255 & .050 & .129 & .792 \\
\hline Organizational standardization & .303 & .416 & .195 & .202 & .126 & .091 & .695 \\
\hline Activity Rules setting & .494 & .435 & .243 & -.014 & .089 & .097 & .531 \\
\hline Participation Frequency & .186 & .170 & .898 & .078 & .143 & .029 & .093 \\
\hline Public Welfare Participation Channel & .087 & .111 & .861 & .184 & .122 & .193 & .090 \\
\hline
\end{tabular}

Extraction Method: Principal Component Analysis.

Rotation Method: Varimax with Kaiser Normalization.

a. Rotation converged in 7 iterations.

\section{Results}

\section{A. Evaluation Results of Community Time Bank Mutual Assistance Service Performance}

Based on the $3 \mathrm{E}$ methodology, the evaluation procedure of community time bank mutual assistance service performance is the following steps.

Firstly, the average score of each item is calculated (the total score of each item is 7 points), as shown in Table VI.

TABLE VI

DESCRIPTIVE STATISTICS

\begin{tabular}{|c|c|c|}
\hline & $\mathbf{N}$ & Mean \\
\hline Material Resource Input & 303 & 5.043 \\
\hline Human Resource Input 1 & 303 & 5.030 \\
\hline Human Resource Input 2 & 303 & 5.277 \\
\hline Service Amount & 303 & 3.723 \\
\hline Service Quality & 303 & 4.063 \\
\hline Personal Effect & 303 & 5.149 \\
\hline Community Effect 1 & 303 & 5.096 \\
\hline Community Effect 2 & 303 & 5.162 \\
\hline Social Effect & 303 & 5.096 \\
\hline Valid N (listwise) & 303 & \\
\hline
\end{tabular}

Then, the confirmatory factor analysis on the time bank variables was done by Amos 24.0. The results are shown in Table VII. 


\section{TABLE VII}

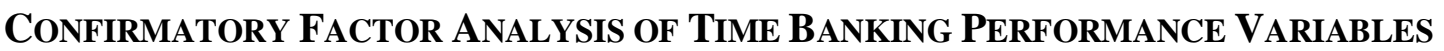

\begin{tabular}{|c|c|c|c|c|c|c|}
\hline & & & Estimate & S.E. & C.R. & $\mathbf{P}$ \\
\hline Economy & $<--$ & time banking performance & 1.000 & .776 & & \\
\hline Efficiency & $<---$ & time banking performance & 1.081 & .770 & 9.235 & $* * *$ \\
\hline Effectiveness & $<---$ & time banking performance & 1.377 & .903 & 10.292 & $* * *$ \\
\hline Material Resource Input & $<---$ & Economy & 1.000 & .873 & & \\
\hline Human Resource Input 1 & $<--$ & Economy & 1.010 & .837 & 18.229 & $* * *$ \\
\hline Human Resource Input 2 & $<---$ & Economy & 1.062 & .880 & 19.581 & $* * *$ \\
\hline Service Amount & $<---$ & Efficiency & 1.000 & .797 & & \\
\hline Service Quality & $<---$ & Efficiency & 1.235 & .882 & 12.960 & $* * *$ \\
\hline Personal Effect & $<---$ & Effectiveness & 1.000 & .886 & & \\
\hline Community Effect 1 & $<--$ & Effectiveness & .920 & .791 & 17.503 & $* * *$ \\
\hline Community Effect 2 & $<--$ & Effectiveness & 1.010 & .894 & 21.914 & $* * *$ \\
\hline Social Effect & $<---$ & Effectiveness & 1.035 & .818 & 18.564 & $* * *$ \\
\hline
\end{tabular}

From the analysis above, the evaluation result is: $(5.04 * 0.87+5.03 * 0.84+5.28 * 0.88) * 0.78+(3.72 * 0.80+4.06 * 0.88) * 0.77+(5.15 * 0.89+5.10 * 0.79+5.16 * 0.89+5.10 * 0.82)$ $* 0.90=31.02$, and the overall score is: $(0.87+0.84+0.88) * 7 * 0.78+(0.80+0.88) * 7 * 0.77+(0.89+0.79+0.89+0.82) * 7 * 0.9=44.55$. The score above convert to a percentage system is 69.63 points. Therefore, the evaluation result of community time bank mutual assistance service performance is considered to be at a medium level.

\section{B. Hypothesis Testing}

The confirmatory analysis was done by Amos 24.0. The results are shown in Table VIII.

\section{TABLE VIII}

\section{FitTing Results OF STRUCTURAL EQUATIONS}

$\begin{array}{ccc}\text { Economy } & <--- & \text { External Supervision } \\ \text { Efficiency } & <--- & \text { External Supervision } \\ \text { Effectiveness } & <--- & \text { External Supervision } \\ \text { Economy } & <--- & \text { Organizational Credibility } \\ \text { Efficiency } & <--- & \text { Organizational Credibility } \\ \text { Effectiveness } & <-- & \text { Organizational credibility } \\ \text { Economy } & <--- & \text { Organization Management } \\ \text { Efficiency } & <--- & \text { Organization Management } \\ \text { Effectiveness } & <--- & \text { Organization Management } \\ \text { Economy } & <--- & \text { Public Welfare Atmosphere } \\ \text { Efficiency } & <--- & \text { Public Welfare Atmosphere } \\ \text { Effectiveness } & <--- & \text { Public Welfare Atmosphere }\end{array}$

From the results in Table VIII:

The standardized path coefficient of external supervision to the time bank's economy is $-0.005(\mathrm{P}=0.891>0.05)$, which shows no significant correlation between the external supervision and the time bank's economy (Hypothesis 1-1 cannot be supported). This may be because the Nansha Time Bank is an online platform. Most of the external supervision is based on how the online platform operates but little is known about the actual use of office equipment and facilities, so there is no obvious relationship between the two. The standardized path coefficient of external supervision to the time bank's efficiency is 0.224 ( $\mathrm{P}<0.05)$, which shows a positive correlation, indicating that with the strengthening of external supervision; the time bank is more efficient (Hypothesis 1-2 is supported). The standardized path coefficient of external supervision to the time bank's effectiveness is 0.157 ( $\mathrm{P}<0.05$ ), which shows a positive correlation, indicating that with the strengthening of external supervision; the time bank is more effective (Hypothesis 1-3 is supported).

The standardized path coefficient of organizational credibility to the time bank's economy is $-0.006(\mathrm{P}=0.874>0.05)$, which shows no significant correlation between the organizational credibility and the time bank's economy (Hypothesis $2-1$ 


\author{
E-ISSN: 2469-6501 \\ VOL: 6, ISSUE: 2 \\ February/2020 \\ DOI:10.33642/fjbass.v6n2p1 \\ https://ijbassnet.com/
}

cannot be supported). This may be because the increase in the credibility of the organization brings about an increase in the participation and trust of time bank's online platform, while the economy of time bank measures the offline input of materials and human resources. The standardized path coefficient of organizational credibility to the time bank's efficiency is 0.388 ( $\mathrm{P}$ $<0.05$ ), which shows a positive correlation, indicating that with the improvement of organizational credibility; the time bank is more efficient (Hypothesis 2-2 is supported). The standardized path coefficient of organizational credibility to the time bank's effectiveness is $0.322(\mathrm{P}<0.05)$, which shows a positive correlation, indicating that with the improvement of organizational credibility; the time bank is more effective (Hypothesis 2-3 is supported).

The standardized path coefficient of organizational management to the time bank's economy is $0.906(\mathrm{P}<0.05)$, which shows a positive correlation, indicating that with the enhancement of organizational management; the time bank is more economical (Hypothesis 3-1 is supported). The standardized path coefficient of organizational management to the time bank's efficiency is 0.478 ( $\mathrm{P}<0.05)$, which shows a positive correlation, indicating that with the enhancement of organizational management; the time bank is more efficient (Hypothesis 3-2 is supported). The standardized path coefficient of organizational credibility to the time bank's effectiveness is $0.741(\mathrm{P}<0.05)$, which shows a positive correlation, indicating that with the enhancement of organizational management; the time bank is more effective (Hypothesis 3-3 is supported).

The standardized path coefficient of public welfare atmosphere to the time bank's economy is $0.014(\mathrm{P}=0.686>0.05)$, which shows no significant correlation between the public welfare atmosphere and the time bank's economy (Hypothesis 4-1 cannot be supported). This may also be because the improvement of the public welfare atmosphere is related to residents' enthusiasm to participate in online platforms but has no obvious relationship with the offline equipment and manpower. The standardized path coefficient of public welfare atmosphere to the time bank's efficiency is 0.263 ( $\mathrm{P}<0.05$ ), which shows a positive correlation, indicating that with the improvement of public welfare atmosphere; the time bank is more efficient (Hypothesis 4-2 is supported). The standardized path coefficient of public welfare atmosphere to the time bank's effectiveness is $-0.040(\mathrm{P}=0.298>0.05)$, which shows no significant correlation between the public welfare atmosphere and the time bank's effectiveness (Hypothesis 4-3 cannot be supported). This may be because when the social public welfare atmosphere improves, residents are more likely to participate in other unpaid public welfare projects, so it may not contribute much to the effectiveness of time banks on the individuals, communities and society.

\title{
V. Discussion
}

\section{A. Conclusions}

Based on the $3 \mathrm{E}$ performance evaluation theory, in this study, the performance of community time bank mutual assistance services is empirically evaluated from three aspects of the economy, effectiveness, and efficiency. Based on the existing research results and field investigations, we hypothesize four impacts on the $3 \mathrm{E}$ performance of community time bank mutual assistance services, including external supervision, organizational credibility, organizational management, and public welfare atmosphere. The relevant empirical data from Nansha District, Guangzhou, China are used as samples in the Structural Equation Model to empirically test the above hypotheses. The results show that: first, the performance of community time bank mutual assistance services is at a medium level; second, external supervision has a positive effect on the efficiency and effectiveness of time bank mutual assistance services, but no significant relationship with economy; third, organizational credibility has a positive effect on the efficiency and effectiveness, but no significant relationship with economy; forth, organizational management has a positive effect on the economy, efficiency and effectiveness; fifth, public welfare atmosphere has a positive effect on the efficiency, but no significant relationship with economy and effectiveness.

\section{B. Recommendations}

First, government supervision and relevant laws and regulations should be strengthened. Government supervision is the most important way of external supervision, which has a great impact on the performance of community time bank mutual assistance services. As the client of time banks, the government is responsible for the investment of funds and manpower. It is necessary to measure whether the investment has been effectively used through a series of approaches to supervision. In addition, enhancing the relevant laws and regulations of time banking also provides institutional protection for the sustainable development of time banks, which thus improves the residents' confidence and willingness in their participation. 
Second, the members' feedback and publicity should be paid attention to. Reputation is the most important factor affecting organizational credibility, and it has an important influence on the performance of community time bank mutual assistance services. Members, the major participants of time banks, will form their own ideas and opinions about time banks. The organizers of time banks should pay attention to members' feedback and opinions after their participation in mutual assistance services and consider the solution to satisfy the members. The more satisfied the members are, the more likely that they recommend time banks to others. Together with the propaganda, the reputation of time banks will be improved, which definitely benefits its further development.

Third, the organizational structure should be compatibly arranged and rules should be more complete. The organizational structure and organizational standardization are the core factors affecting the organization and management of time banks. It is not only necessary to invite experts of organizational management to give professional advice, but also to solicit opinions from the public, and to improve it together with actual practice. In addition, as a platform, time banks should strictly follow the standardized process and properly solve the problems that occurred during the services to ensure the implementation of the services, which will foster the residents' trust on time banks.

Fourth, the channel of participation in public welfare should be broadened and a good public welfare atmosphere should be formed. The public welfare channel, the most important factor that affects the public welfare atmosphere, will have a positive impact on the performance of community time bank mutual assistance services. The government should take actions to broaden the channels and diversify residents' options of participating in the public welfare, which will attract more residents to participate and form a good public welfare atmosphere. When residents increase their awareness of public welfare, they will accept the concept of time banking and thus increase their participation.

\section{Limitations and Prospects}

Limited by the resource support, we only investigate and collect data for a time bank in one region, which may cause some regional deviations, and affect the universality of the research results. Wider coverage of the sample data is recommended to be obtained in the future so that the research conclusions can be more widely applied. For example, the relevant data of time banks in Tianjin, Shanghai, Dongguan and other places are suggested to be included in the sample. In addition, the factors affecting the performance of time banks are far more than the four factors in our study. Under the further practice of time banks and the changes in the social environment, other influencing factors are recommended to be focused on, so as to provide relevant policy recommendations for the sustainable development of time banks.

\section{Funding}

This work was supported by the Students Innovation and Entrepreneurship Training Program of Guangdong Province, China (No. 201811846027).

\section{Acknowledgments}

We wish to acknowledge Prof. Bin Tu, the supervisor of this work. Also, we would like to thank the following people for their participation: Peina Lin, Zhuoli Chen, and Wanghua Liu.

\section{REFERENCES}

D. Boyle, "The new mutualism and the meaning of Time Banks", Local Economy, vol. 18, pp. 253-257, 2003.

E. S. Cahn, No more throw-away people: the co-production imperative, 2nd ed., Washington, DC: Essential Books, 2004.

Ed. Collom, "Engagement of the elderly in Time Banking: the potential for social capital generation in an aging society", Journal of Aging \& Social Policy, vol. 20, pp. 414-436, 2008.

G. Chen, G. G. Huang, "The localized development, practice and innovation of Time Banks in China: on the ageing of population in China”, Journal of Peking University (Philosophy and Social Sciences), vol. 54, pp. 111-120, 2017.

G. Chen, P. Du, Y. Chen, "A think on the time-saving problems of supporting the old, Population \& Economics, vol. 06, pp. 67-73, 2001. 
G. Seyfang, "Harnessing the potential of the social economy? Time banks and UK public policy", International Journal of Sociology and Social Policy, vol. 26, pp. 430-443, 2006.

G. Seyfang, "Time banks: rewarding community self-help in the inner city", Community Development Journal, vol. 39, pp. 6271, 2004.

G. X. Ma, "The applications of 'Time Bank' mode in aging care at home", Journal of Nanjing University of Science and Technology, vol. 23, pp. 116-120, 2010.

G. Z. Mu, "Establish an intergenerational mutual assistance system and get out of the traditional pension dilemma", Market and Demographic Analysis, vol. 05, pp. 33-35, 1999.

H. H. Lin, “The research on the community 'Time Bank' from its development straits and solutions”, Journal of Social Work, vol. 12, pp. 68-70, 2012.

H. W. Zhou, Y. Shen, “Time saving and volunteer willingness for urban aged care in aging era”, vol. 22, pp. 69-75, 2013.

J. Jing, R. Zhao, “Mutual support for the elderly: enlightenment from 'Love Time Bank', Thinking, vol. 41, pp. 72-77, 2015.

J. Lasker, Ed. Collom, T. Bealer, et al., "Time banking and health: the role of a community currency organization in enhancing well-being", Health Promotion Practice, vol. 12, pp. 102-115, 2011.

J. M. Xu, "The consideration about the application of 'Time Bank' mode into mutual service of based housing support, Journal of Social Work, vol. 01, pp. 74-80+126-127, 2015.

J. Soukopová, M. Struk, (2011, June), "Methodology for the efficiency evaluation of the municipal environmental protection expenditure", Environmental Software Systems, vol. 359, pp. 327-340, 2011.

L. Wang, "A new mode of cyclical mutual assistance-Time Bank”, Legal System and Society, vol. 09, pp. 189-190, 2011.

M. B. Marks, "Time banking service exchange systems: A review of the research and policy and practice implications in support of youth in transition”, Children and Youth Services Review, vol. 34, pp. 1230-1236, 2012.

M. Y. Chen, B. B. Cai, “A preliminary research on the application of 'Time Bank' Mode to Social work of leisure youth, Legal System and Society, vol. 06, pp. 192-194, 2013.

R. M. Yao, "Difficulties and solutions: research on the construction of social organizations' credibility", Academic Journal of Zhongzhou, vol. 01, pp. 62-67, 2013.

S. J. Li, "A brief discussion about the current situation, problems and countermeasures of China's volunteer Time Bank development", Economic Research Guide, vol. 03, pp. 102-104+108, 2015.

X. P. Xia, “China's mutual aid 'Time Bank' localization development and experience reflection", Chinese Journal of Gerontology, vol. 37, pp. 5723-5725, 2017.

X. Y. Fei, S. Y. Cui, "Study on the public awareness and participation of Time Bank", Value Engineering, Vol. 32, pp. 1-3, 2013.

Y. H. Chen, Y. N. Shi, “Time Bank: origins, problems, and prospects”, The Journal of Humanities, vol. 12, pp. 111-118, 2015.

Z. F. Deng, "The consideration on the construction of 'Time Bank' for the elderly service in China", Journal of Nanjing College for Population Programme Management, vol. 28, pp. 17-21+43, 2012.

Z. H. Wang, "Time Bank-a new form of community volunteer service”, Community, vol.12, pp. $23,2003$. 